\title{
External and internal factors in organizational budgeting methodology formation
}

\author{
Kira Gulpenko ${ }^{1}$, Natalia Tumashik $^{1,{ }^{*}}$, Yulia Filiasova $^{1}$ \\ ${ }^{1}$ Saint-Petersburg State University of Economics, Sadovaya str., 21,St.-Petersburg, 191023, Russia
}

\begin{abstract}
External and internal factors affecting budgeting methodology are analyzed in the article. Modern approaches to organizational budgetary policy development which are described in the scientific literature on economics and applied in practice are investigated. Strategy-, process-, project- and risk-oriented types of budgeting are of particular interest in the article.
\end{abstract}

\section{Introduction}

Modern trends in economy have reinforced the effects of external and internal factors onto budget preparation and utilization.

External factors which influence the process of budgeting allow developing methodological techniques related to basic approaches to budgeting. Competition, scientific and technological progress, international relations, macro- and microeconomics, a political situation and the social segment are among such factors.

Budgeting in modern conditions is also carried out under the influence of internals factors, such as the following:

- industrial;

- technological and organizational;

- human resources;

- automation and corporate information systems [1].

Every industry has its own specific budgeting characteristics which are explained by distinctive features of the industry itself.

Multiple factors of an external environment, a variety of activities performed by a business unit, managerial tasks and budgeting goals affect the choice and combination of approaches to budgeting. The main approaches to budgeting are the following:

- result-oriented budgeting;

- $\quad$ strategic budgeting;

- $\quad$ process-oriented budgeting;

- project-oriented budgeting;

- risk-oriented budgeting;

- scenario-oriented budgeting;

- elastic budgeting;

- $\quad$ budgeting from scratch;

*Corresponding author:Tumnatdim@yandex.ru 
- increment-based budgeting;

- prescriptive budgeting;

- flexible budgeting;

- authoritarian "from-top-to-bottom" budgeting;

- participative "from-bottom-to-top" budgeting;

- consultative budgeting;

- composite budgeting;

- others.

The conceptual issues of result-oriented budgeting are as follows:

- planning of expenditure on the basis of performance results obtained as a result of social and economic activities;

- budget allocation depending on the level of indicator achievements in the social and economic activities;

- freedom of choice how to achieve goals and objectives granted to budget holders;

- responsibility of budget holders and recipients of budgetary funds for the ultimate outcome;

- orientation of budget control towards internal audit of cost efficiency and external control over targeted use of budgetary funds.

Research into practice in the application of result-oriented budgeting shows that this approach is implemented in organizations funded with budget provisions. It is pointed out that despite the theoretical overview; methodological approaches require further to be implemented in business units.

Progress in strategic management has influenced various areas of concern in planning, auditing, calculation and budgeting. A new approach is strategy-oriented budgeting which is characterized by the following features:

- corporate strategy development;

- application of methods and tools - a balanced scorecard (BSC) and its specified elements;

- determination of cause-and-effect relations in the BSC;

- establishment of relations between budgets and elements of the BSC;

- derivation of outcome indicators which represent the level of achieving strategic goals in the operating activities on the basis of prepared budgets .

The features mentioned are intensively studied in academic works from different perspectives. In particular, many publications are devoted to the development and practical implementation of a balanced scorecard targeted at an adopted strategy. The balanced scorecard is aimed at meeting a complex of objectives in practice; the corresponding budgets have to be prepared within the scope of these objectives.

The methodology of strategy-oriented budgeting is closely connected with processoriented budgeting, which incorporates two management strategies:

- business performance;

- costs.

The former involves implementation of a balanced scorecard. The latter is based on an incremental introduction of activity-based management (ABM) including activity-based costing $(\mathrm{ABC})$ and activity-based budgeting (ABB).

Activity-based budgeting is instrumental in:

- forming non-financial indicators which characterize the process and its outcome;

- developing the structure of processes' costs and determining their target prime cost;

- tracking costs of each center for financial responsibility.

- estimating efficiency of each process;

- appraising performance of centers for financial activity and the entire company. 
The described approached combines a complex of various financial and non-financial indicators developed to be applied to a certain strategy, business processes and centers for responsibility.

A specific approach is project-oriented budgeting used in one-off production, research and development, and so on.

Project-oriented budgeting embraces the following activities:

- budget preparation and their consolidation;

- monitoring project costs of any kind and analysis of plan/actual;

- cash flow management of individual projects, programs, portfolio of projects;

- operative re-planning of financial resources when changing the schedule and the scope of work in a project;

- $\quad$ exact prediction of financial needs for successful completion of a project;

- analysis of financial indicators as a result of performance at centers for financial responsibility and project managers' performance.

The authors of this article believe that the objects of process-oriented budgeting can be divided into the following groups:

- objects being part of operating activities involved into projects: operating processes, stages, types of work, centers for responsibility, outcomes;

- objects providing the realization of operating activities for projects: assets, liabilities, sources of financing, income and expenditure;

- information about the external environment and risks affecting the operating activities of a company in relation to its projects.

A variety of factors which appeared in the macro- and micro-economic situations, being external factors in relation to an organization, became the reason for appearing risk-oriented budgeting. The notion "risk" has connections with various aspects of the national economy, branches of industry, particular activities, and companies. It is not a coincidence that various theories of risk come into scientific literature. They are connected with economic, social, environmental and other issues. Budgeting sometimes incorporates such approaches which are focused on risks and risk management.

Risk-oriented budgeting involves:

- taking into consideration the risk profile of a company, its departments and operating activities;

- generation of income, expenditure and missed profit in a company connected with assuming or avoiding risks;

- better record-keeping in financial risk evaluation and value of their management or abandoning management in the budgeting process;

- changing the budgeting process by including risk management measures;

- recording the following information in budget items or in a separate budget for financial risk management: the magnitude of evaluated financial risks as of the budgeting process; value assessment of financial risk management by means of every possible method for each particular risk;

- correction of the budget after additional financial risk identification in the process of budget execution;

- changing the flow of documents as a result of corporate information stream consolidation and transformation;

In the academic literature, there are other approaches to budgeting which emerged in various business environments, such as "market-driven approach", "result-oriented approach", "production-driven approach" - they are widely used in practice.

In the case of adopting the market-driven approach, the first step is income generation which becomes the evidence for the market potential of a company. Sales forecast within the target period serves as its framework. Afterwards, expenditure budget is developed as a 
derivative of revenue and represents input requirements indispensible for obtaining the planned income. Such an approach is taken by companies which effectively operate on the market and have an opportunity to predict their sales volumes with required precision.

When utilizing the result-oriented approach, goals achieved within the previous period are taken as a framework for preparing a budget for the coming period - this may refer to both the income and expenditure item. That being the case, either of them can be taken as a basis, for instance, an attained expenditure level; then, the revenue level, essential for covering the expenditure and ensuring further reproductive performance and development of the company, is determined. It is possible to take a reverse action by increasing the revenue item by the amount of the intended increment and use this for calculating the expenditure item. This approach is relatively simple and suits those companies whose activities are steady in time - one period is slightly different from another.

The production-driven approach is used in companies with bespoke production of products or services. The generation of revenue item (sales forecast) is often complicated by the fact that orders are significantly different from one another in volume; they are unique, irregular, and so on. In this case, the framework for budget planning may become the intended (or predicted) increase in output, measured in physical units (on the condition that any order can be easily and accurately converted into these units of measurement). Therefore, the income item of the budget is defined on the basis of the predicted sales volume in average selling prices per unit of measure. The quantity and volume of orders which ensure the budget fulfillment are not important.

Depending on the range of indicators, there are different types of budgeting: total, necessary, minimal budgeting and budgeting for income and expenditure.

Total budgeting involves regular planning of all corporate functions in all company activities. Each function can be represented as a set of objectives to be met. The realization of this type of budgeting includes analyzing the functional organizational structure and preparing operational (and financial) budgets for each functional area. This approach is applied in large organizations which have sufficient number of assets critical for its implementation.

The necessary budgeting is based on regular preparation of operating budgets just enough for computation of end-of-year financial budget. The structure of operating budgets can be called standard. In the framework of operating budgets, business processes and operations is planned generally, without any details at the level of individual departments.

Minimal budgeting embraces only three financial budgets. The sources of information are reports of the prior periods, contractual documents with suppliers and customers, among others, but not operating budgets. The main goal of this budgeting is fulfilling the function of budget planning

Budgeting for income and expenditure is compiled for one year with quarterly segregation. The explanatory note includes sources and periods of income acquisition, priorities for income utilization, deficit funding methods (e.g. loans) and principles of surplus allocation among budget items of expenditure. The budget of revenue and expenditure items cannot ensure compatibility with accounting statements; it does not allow for cash flow management or coordination of sales, production, logistic and financial activities.

\section{Conclusion}

The modern state of economy requires application of new management procedures depending on the internal climate in a business entity which can be derived from traditional approaches through their modern interpretation and developed on the assumption of goals and objectives to be met. Budgeting is considered as a detailed policy plan of a business 
unit containing both physical and monetary estimates, thus being a management tool. Currently, there are various methodological approaches to budgeting and their application is dependent on goals to be achieved and management techniques. External and internal factors affecting business unit activities have been considered. The influence of industry characteristics, technologies, business unit administration and multi-factorial external environment has resulted in developing the main approaches to budgeting in the modern economic climate and defining new methods of its realization.

\section{References}

1. K.V.Gulpenko, N.V. Tumashik, Relevant issues of estimation in economic sectors(Prospect,Moscow, 2017)

2. K.V.Gulpenko, N.V. Tumashik, Accounting reports as information base for social and economic system management(Saint-Petersburg State University of Economics,St.Petersburg, 2012)

3. E.B. Maievskaia, Strategic analysis and cash flow budgeting in commercial organizations(Infra-M,Moscow, 2016)

4. V.Yu. Savin, Auditing and Financial Analysis2, 34-41 (2011)

5. M.B. Trachenko, Budgeting in the financial management system, 38 (2012)

6. V.E.Khrutsky,V.V. Gazmaiunov, Internal budgeting: Theory and practice (Yurite,Moscow, 2017) 